\title{
Juvenile Type Testicular Granulosa Cell Tumor
}

National Cancer Institute

\section{Source}

National Cancer Institute. Juvenile Type Testicular Granulosa Cell Tumor. NCI Thesaurus.

Code C39947.

A rare sex cord-stromal tumor that arises from the testis. It is the most frequent congenital testicular neoplasm and is usually diagnosed during the perinatal period. It usually presents as an asymptomatic scrotal or abdominal mass. Morphologically it is characterized by the presence of cysts that are lined by cells resembling granulosa and theca cells. 